総 説

\title{
前庭誘発筋電位
}

將積日出夫 ${ }^{1)}$ - 竹森 節子 ${ }^{2)}$ - 渡辺 行雄 ${ }^{1}$

\section{Vestibular Evoked Myogenic Potentials}

\author{
Hideo Shojaku ${ }^{1)}$, Setsuko Takemori ${ }^{2)}$, Yukio Watanabe ${ }^{1)}$ \\ 1) Department of Otolaryngology, Toyama Medical and Pharmaceutical University \\ 2) Department of Neurotology, Toranomon Hospital
}

Intense clicks evoke short-latency myogenic potentials on the sternocleidomastoid (SCM) muscle ipsilaterally. These potentials are named "vestibular evoked myogenic potentials (VEMP)" because they are lost after vestibular deafferentation, but independent of the cochlear function. To induce VEMP, the subjects need to contract their SCM muscle during the test. The characteristics of the tuning curve of VEMP are a high threshold and low best frequency. They are similar in animal studies, suggesting that the saccule is the most promising candidate for the origin. Some diagnostic merit has been reported in previous papers. First, there is a discrepancy between VEMP and caloric response in patients with both inner ear and retrolabyrinthine disorders. Therefore, the test battery of these two tests is very useful for diagnosing vertiginous patients. Second, the Tullio phenomenon, the phenomenon of vertigo or loss of balance due to intense sound, is also evaluated by using VEMP. The Tullio phenomenon has been found in patients with various disorders, including congenital syphilis, Meniere's disease and perilymphatic fistula. VEMP are expected to be used in a new vestibular function test to evaluate the neural pathway from the saccule to the SCM muscle.

Key words: saccule, vestibulocollic reflex, evoked myogenic potentials

\section{1.はじめに}

音刺激により生体の各部位に誘発筋電位が記録 される。これまで報告された音刺激による誘発筋 電位は，その起源から蝸牛性と前庭性に分けられ る。1963年 Kiang ら 反応 (Postauricular response) は, 耳介後部に探 查電極を扣き，刺激開始から $30 \mathrm{msec} の$ 間に，3 相性の波形が記録される反応2)であり，蝸牛性の 誘発筋電位として広く知られている。一方，1964

1) 富山医科薬科大学耳鼻咽喉科学教室

2) 虎の門病院神経耳科
年 Bickford 5 $5^{3)}$ は，探查電極を外後頭隆起にお。 く Inion Response ${ }^{4)}$ が，刺激から 6-8 msec で開 始し， $50 \mathrm{msec}$ 以内に 4 相性の波形が記録される 反応であり，(1)龍症例では正常反応を示し，(2)前 庭機能廃絶症例では反応消失することから, 前庭 性の誘発筋電位であることを報告した。さらに， 1971年 Townsend, Cody ${ }^{5)}$ は, Inion Response がメニェール病に対する内リンパ減荷術（Tac Operation $^{6)}$ ) 後症例ではみられないため, 球形桽 がその起源として最有力であることを推定した。 Inion Response 性最初の前庭性の誘発筋電位と して報告されたが，頭皮上記録のため神経原性反 
応（中間潜時反応）が混合し両者の分離が困難な 場合が多いなどの問題が指摘され，前庭機能検査 としてよりも，むしろ中間潜時反応記録時のノイ ズとしての面がクローズアップされていた7)。そ れから約 20 年後, Colebatch, Halmagyi ${ }^{8)}$ は探查 電極を胸鎖乳突筋 (SCM) に扣き, 強大音により 刺激開始から $50 \mathrm{msec}$ 以内に記録される 4-5 相 性の誘発筋電位を記録した。このうち $30 \mathrm{msec}$ 以内に観察される 2 相性の反応は, 前庭神経切断 術後に消失，龒症例では観察されるため，前庭頸 反射による誘発筋電位であると考兄られ clickevoked vestibulocollic reflex ${ }^{9)}$ と名付けられた。 彼らは後に Vestibular Evoked Myogenic Potentials（前庭誘発筋電位：VEMP) ${ }^{10 ）}$ と命名し, 球 形囊機能を調べる新しい前庭機能検査として紹介 した。本稿では，このVEMP の臨床的意義とそ の基礎的背景沉ついて概説する。

\section{VEMP 検査方法9) 11) 16)}

VEMP 記録には，音刺激可能な誘発電位記録 装置を使用する。ヘッドホーンから片側耳に強大 音刺激を行ない，対側耳には通常刺激音より -30 $\mathrm{dB}$ 程度の白色ノイズによるマスキングを与え る。音刺激にはクリック音（持続時間：0.1ー0.2 $\mathrm{msec}$ ）用い, 刺激音厈は閾值上 $100 \mathrm{~dB}$ 程度, 刺激頻度は 3-5 Hz, 解析時間は $100 \mathrm{msec}$, 加算 回数は200-500回と設定する。記録電極には 2 組 の脳波用銀血電極を用い，左右胸鎖乳突筋上の皮 膚表面に 1 組ずつを接着して，基準導出を行な 5。探查電極，基準電極と接地電極はそれぞれ SCM 吻尾側 2 分の 1 , 胸骨頭の起始部上と前額 部に牤き，帯域フィルタは $5 \mathrm{~Hz}$ から $1.5 \mathrm{kHz}$ 付 近に設定する。

電気生理学的に, VEMP の振幅と検査時の筋 緊張との間には強い正の相関関係がある9111)。そ こで検査中は SCM の緊張を維持するため, 諾家 により様々な指示が被検者に与兄られている。ま

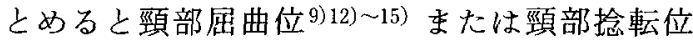
9)16)の $2 つ の$ 姿勢が検査に用いられている。頸部 屈曲位のらち, 特に“仰臥位で頭部を僅かに挙上 する姿勢” は欧米の施設で一般的に用いられてい

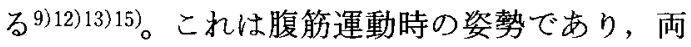
側の SCM に極めて強い筋緊張を与えることが可 能である。したがって，良好なVEMP を記録す ることができる。但し，反応の再現性をみるため
検査を繰り返し行なら必要がある場合には，健常 若年被検者でもこの姿勢を維持することに苦痛を 訴え，検査を中断しなければならない場合があ る16)。とのため，頸部を刺激側と反対方向に回旋 する頸部捻転位を維持させる工夫がなされてい る。検査中の筋電困をモニターして干渉波を 200 $\mu \mathrm{V}$ 以上に保たせるよう注意することで，頸部捻 転位でる頸部屈曲位と同様, 殆どの健常被検者で 良好な VEMP の波形を観察することができる。 体格や年踰の異なる様々なめまい患者に対して， 苦痛をより少なく検査を施行するためには，頸部 捻転位を用いることが望ましい16)。今のところ 7 歳から91歳までの症例で正常な VEMP 反形が記 録可能である。頸部捻転位で VEMP 検查をする と, 石耳刺激では左頸部捻転時に右（刺激側） SCM のみに誘発筋電位が記録される。右頸部捻 転により左（非刺激側）SCM の筋緊張を高めて も誘発筋電位は観察されない。頸部屈曲位による 研究からはVEMP が耐側性 12)14) か同側性 10113)15) かで論争があるが，頸部捻転位での結果16) は後 者を支持していた。

\section{3. 健常被検者での VEMP}

健常被検者の VEMP（図 1) は, 刺激開始か ら $30 \mathrm{msec}$ 以内に陽性波, 陰性波の順で 2 相性 の波形が発生する。Colebatch, Halmagyi $\left.{ }^{9}\right)$ に上 り強大クリック音刺激により健常被検者での各波

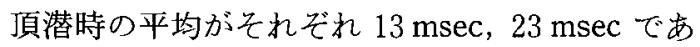
るため，p13，n23 と命名された。頸部捻転位で も平均波頂潜時 ${ }^{16)}$ は，p13 では $13.6 \mathrm{msec}$ (SD $1.90 \mathrm{msec}$ ), n23 では $23.0 \mathrm{msec}$ (SD $2.87 \mathrm{msec}$ ) となり頸部屈曲位9)11)での記録と大差ない。

p13-n23 波頂間振幅恃，刺激音仕之検查中の SCM の筋緊張の程度に依存する。Lim ら ${ }^{11)}$ によ り, p13-n23 波頂間振幅 $(z)$, 刺激音圧 $(\mathrm{x})$, $\mathrm{SCM}$ の筋緊張の定量的分析結果 (y) の3 者は, $\mathrm{z}=5.156 \mathrm{x}+0.403 \mathrm{y}-715$ とい5公式で近似され る。

VEMP の閾值は，健常被検者では平均 87.8 $\mathrm{dB}(\mathrm{SD} 7.9 \mathrm{~dB})$ ，最小䦨值は $75 \mathrm{~dB}$ である16)17)。 $\mathrm{ABR}$ と異なり，刺激音厈を闌值付近まで下げて も $\mathrm{p} 13, \mathrm{n} 23$ ともに潜時の延長はみられな(9)11)。

\section{VEMP の臨床的意義}

(1) 前庭神経切断術

難治性めまい患者に対する外科的治療法である 


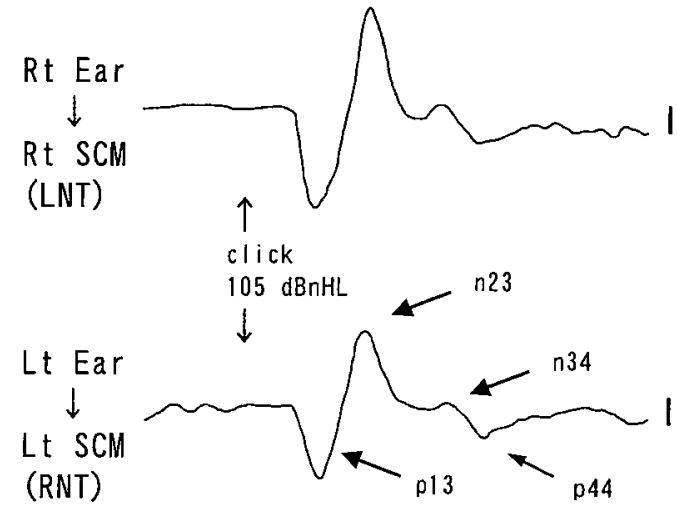

M.C. 30 y. 0 . 女

SCM : 胸鎖乳突筋

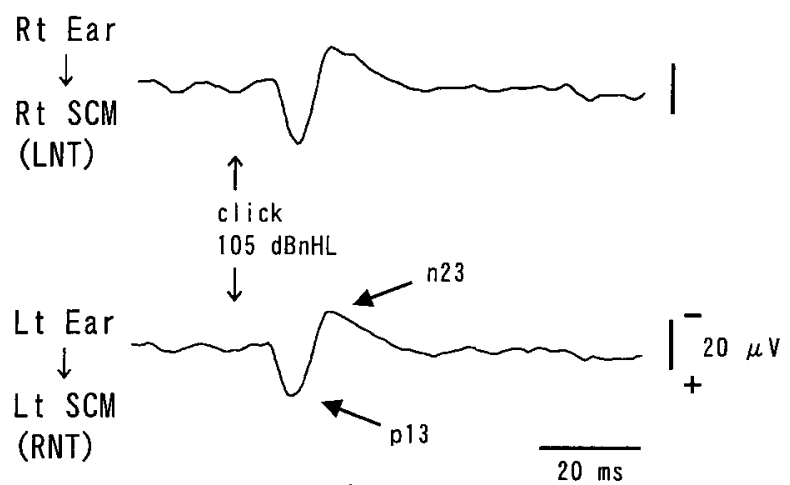

M. N. 21 y. o. 女

図 1 健常被検者 2 名の VEMP

$105 \mathrm{dBnHL} ク リ ッ ク$ 音刺激開始時点は垂直方向の矢印で示した。上段が右耳刺激で左頸部捻転時の右胸 鎖乳突筋 $(\mathrm{SCM})$ 導出記録。下段が左耳刺激で右頸部捻転時の左 SCM 導出記録（文献16より改变)。

VEMP の各波頂は出現潜時から Colebatch $5^{10)}$ により $\mathrm{p} 13, \mathrm{n} 23, \mathrm{n} 34, \mathrm{p} 44$ と命名されている。被榆者 により $\mathrm{n} 34, \mathrm{p} 44$ が記録されない者がいる。

前庭神経切断術を施行すると $\mathrm{p} 13, \mathrm{n} 23$ は消失す $3^{8) 9) 18) 。 C o l e b a t c h, ~ H a l m a g y i ~} は$, 前庭神経切断 術前にみられた $13, \mathrm{n} 23$ が, 手術後 3 力月の再 検查時には消失した右メニェール病症例を報告し た。後に, 彼ら ${ }^{918)}$ は前庭神経团断術を施行した 6 症例を追加した。さらに, 將積ら ${ }^{19)}$ 子(図 2) 前庭神経切断術前後に $\mathrm{p} 13, \mathrm{n} 23$ が消失した症例
を報告して和り，それらの波形が末梢前庭器を受 容器とする反応であることは明らかである。p23 に続く陰性波（n34）と陽性波（p44）については 前庭神経切断後も残るため蝸牛由来の可能性 ${ }^{9)}$ が あるが，難聴のない健常被検者の中にも $\mathrm{n} 34 ， \mathrm{p} 44$ が記録されない者が多い(9)16)ので，それらを蝸牛 の機能検查として利用することはできない。

\section{VN切断前}
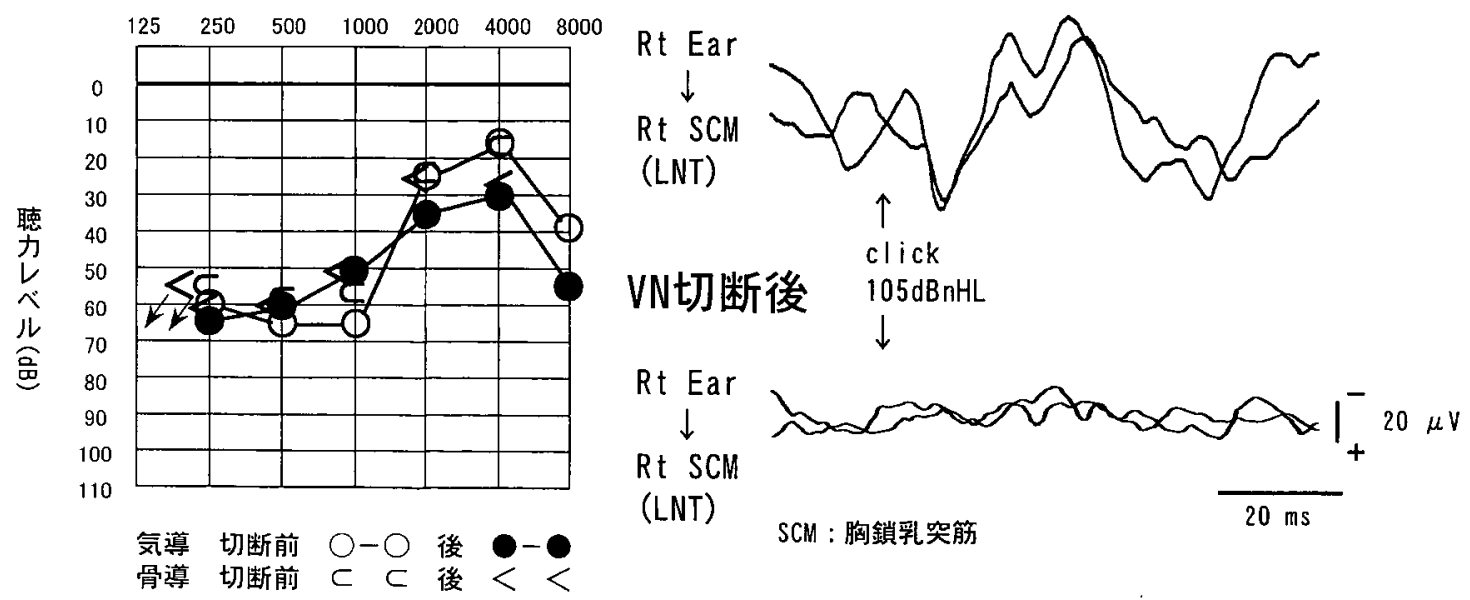

図 2 前庭神経切断患者の VEMP

左図は純音聴力検查結果, 右図に VEMP を示した。 
（2）高度難聴

高度難聴症例では VEMP の正常反応を示す例 があることは諸家の一致した意見である（図 3） 9)12)16)。さらに, 將積ら ${ }^{20)}$ は両側血 8 例で VEMP を施行し p13，n23 を観察したところ，両側正 常, 一側正常, 両側異常はそれぞれ 4 例, 3 例, 1 例であった。以上の結果から $\mathrm{p} 13, \mathrm{n} 23$ は蝸牛由 来の反応ではないと考えられる。

（3）温度刺激検查との解離

温度刺激検査は主に外側半規管の機能検査であ り，VEMP と結果が一致しないことがある。 Colebatch, Halmagyi ${ }^{9)}$ は, 左 CPを示したが VEMP は両側とも正常であっためまいのない両 側䪭症例を報告した。將積ら ${ }^{17)}$ は，めまいを伴 5内リンパ水腫疾患や聴神経腫瘍で CP の程度と VEMP の結果が解離することを指摘した。 Murofushi $5^{21)}$ は, 前庭神経炎症例で $\mathrm{CP} \%$ が 90\%以上でもVEMP は半数で正常であることを 明らかとした。このように内耳障害でも後迷路性 障害22) でも両者の解離が報告されている。外側 半規管の情報は上前庭神経を介して前庭神経核ま で運ばれる。後迷路性障害で外側半規管機能検査 である温度刺激検查が VEMP と解離すること は，VEMP が主に下前庭神経機能を評価してい る可能性を示唆する。この点, 前庭神経炎47例中 回復期に良性発作性頭位眩暈症 (BPPV) を生じ た10症例全例で VEMP が正常であった ${ }^{19 ）}$ と報
告されている。近年, BPPVの成因は後半規管 浮遊耳石によると考皃られるため, BPPV の発 現には下前庭神経を介して運ばれる後半規管の情 報が不可欠である。VEMP 正常例のみで BPPV が観察されたことは，VEMP が主に下前庭神経 機能を評価している可能性をさらに支持した。

(4) Tullio 現象

Tullio 現象は, 強大音によって引き扣こされる めまいと眼振が誘発される徵候で, 1924年に Tullio ${ }^{23)}$ が鳵の外側半規管に瘦孔を作成して報告

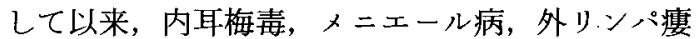
など24) 26) で怙こることが知られてきた。Colebatch ら ${ }^{27)}$ は，大きな音を聞くと不安定になり 左に偏位するといら主訴があり, 左耳に $1 \mathrm{kHz}$ で $110 \mathrm{~dB}$ の純音を与六た場合に水平・垂直・回 旋性眼振が観察された症例に対して VEMP を施 行した。患側では健側に比較して p13，n23 の閾 值の低下と同一刺激音厈での p13-n23 波頂間振 幅の增大がみられて和り, Tullio 現象の新しい診 断法としての VEMP の有用性を報告した。

（5）VEMP と体平衡障害

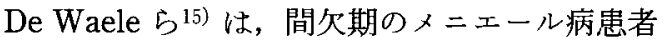
を $\mathrm{CP} \%$ の平均值に差がない，VEMP 消失例と VEMP 正常例の 2 群に分け, 動的体平衡機能検 査装置である Equi Test ${ }^{28)}$ を行なった。その結 果, 6 項目ある Sensory Organization Test (SOT) の検査項目のうち前庭入力に頼って立つことを要

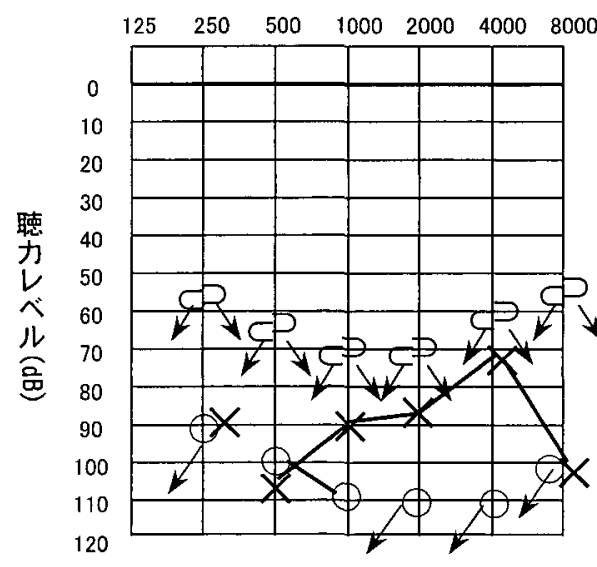

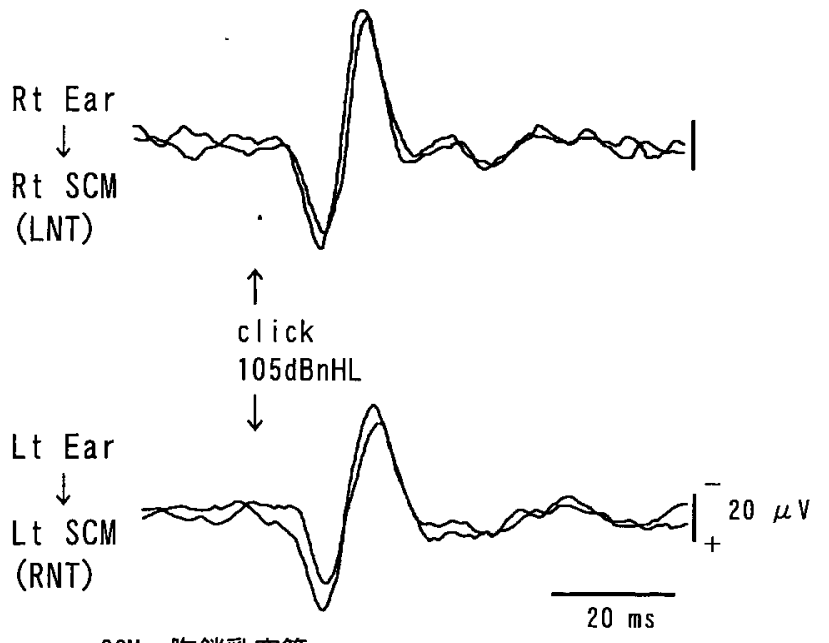

SCM : 胸鎖乳突筋

図 3 右龍, 左高度難聴患者の VEMP（文献16より引用） 
求される条件 5 に扣いて VEMP 消失例では VEMP 正常例に比較して Equilibrium score $か$ 有意に低いことを明らかにして，VEMP 障害に より体平衡障害が生ずることを初めて報告した。 さらに彼らは, 開眼下で SOT 条件 5 と全く同様 の検査を行なら SOT 条件 4 では 2 群間に差を認 めていないことから，VEMP 障害例では代償性 に姿勢保持のため視覚への依存性が増しているこ とを明らかとした。

\section{VEMP の神経経路}

(1) 末梢前庭器

内耳の原基は, 菱脳の外側の体外外肧葉に由来 する。胎生初期に，この部が肥厚して耳板とな り,ついでこの部が陥入し, やがて皮膚から離れ て耳胞となる29)。耳胞は，まず球形囊と即形穓の 2 部に分かれ, 両者の結合部から内リンパ管が出 る。卵形褧の一部は突出して半規管を形成し, 球 形襄の一部は突出して回転して蝸牛管をつくる。 胎生 8 力月前に回転は完成する。このように球形 襄は発生過程で蝸牛と原基をともにすることか ら, 古くより球形囊が直線加速度の他に聴覚に感 受可能である可能性が示唆され, 動物実験により 明らかにされてきた。Cazals ら ${ }^{30)} は$ は，モルモッ トにアミ，配糖体系抗生剂を筋注することにより 蝸牛を破壊した後に，正円空窩に挿入した電極を 用いて, 強大音刺激により脳幹の誘発反応を記録 した。またDidier, Cazals ${ }^{31}$ は, 内耳道入口部 付近の上下前庭神経より直接誘発電位を記録し た。音刺激によりアミノ配穑体抗生剤処置群で得 られる誘発反応は，球形囊神経線維が局在する下 前庭神経の吻側部で最大振幅が得られ, 未処置群 (蝸牛正常) に比較して短潜時であることを発見 した。さらに, Cazals ら ${ }^{32)}$ は, 処置群では外側 前庭神経核 (LVN) にて反応が観察され, 螖牛神 経核では無反応であったことを報告した。このよ らに Cazals らのモルモットでの研究で, 球形襄 は強大音刺激に対して応答し, 蝸牛起源の誘発反 応に比較して短潜時である可能性が示唆され, 後 Kモルモットやネコの研究33) 35) により裏付けら れた。さらに, 神経解剖学的に強大音に応答する 球形囊神経線維が前庭神䅅核に投射することが報 告33) 35) され，その投射部位は LVN，内側前庭 神経核 (MVN) および下前庭神経核 $\left(\right.$ IVN) $\left.{ }^{33)} 35\right)$ であった。サルの球形裳も強大音に応答すること
が報告36）されて招り，ヒト球形製す同様の性質 を持っているものと推定される。

(2) 前庭脊髄路

前庭瓷髄路には，外側前庭沓髄路 (LVST) と 内側前庭脊髄路 (MVST) がある37)。LVSTは, 主にLVNから和こり, 主に耳石器からの入力を 同側性に脊髄全域に投射している。LVST の細 胞は興奮性のみである。一方, MVST は, MVN 牤よびIVNから物こり，主に半規管からの入力 を雨側性に投射し頸䯣レベルで大部分が終わる。 MVST の神経は抑制珄のものが同側を，與奮性 は対側を下降する。このように解剖学的にも生理 学的にも大きく異なっている2 種類の前庭瓷髄路 のどちらをVEMP が経由するかは大きな問題で ありこれまでも諸家により議論されてきた。 Colebatch, Halmagyi ${ }^{9)}$ は, VEMP が同側性で あり，モルモットで球形製が LVN に投射するこ とから LVSTをVEMP の神経経路と推定した。 一方, Ferber-Viart らは，VEMP が両側性反応 であり，サルでは球形豪の投射は MVN と IVN であり，モルモットでみられる LVNへの投射は 殆どないことから, VEMP には MVST が関与 していると Colebatch, Halmagyi の仮説を批判 した。1999年, Kushiro ら ${ }^{38)} に よ る$ 報告はこの 論争を解決した。彼らは, ネコの球形骍神経電気 刺激時に SCM 運動ニューロンの活動電位を記録 した。同側の SCM 運動ニューロンでは，44個中 43個で抑制性シナプス後電位 (IPSP) を記録され た。一方, 対側の SCM 運動ニューロンでは, 31 個中28個で明らかな反応を記録できなかった。さ らに, 菱形窩の下端レベル (Obex) でMVSTを 切断すると球形穰神経電気刺激で40個中全ての SCM 運動ニューロンで IPSP を記録できなかっ た。これらのデータから, 球形䗒から前庭神経核 に伝達された VEMP の情報は, 前庭沓髅路のら ち主に同側性に投射をする MVSTを介して同側 の SCM 運動ニューロンに抑制的に作用して音刺 激と同側の SCM に誘発筋電位を生ずるため, SCM の筋活動が p13-n23 response に一致して 一時的に抑制される ${ }^{39)}$ といらことが明らかとな った。

\section{6. 結 語}

VEMP の臨床的意義と基礎的背景について概 説した。VEMPはこれまで評価が困難で，その 
機能異常について臨床的に殆ど明らかにされてい なかった球形蛪の機能検査法であり, その神経経 路は球形黹一前庭神経一前庭神経核-MVST-SCM 運動ニューロンーSCM と考光られる。またVEMP は，音刺激可能な誘発電位記録装置があれば簡便 で再現性が高く，工夫により被検者の苦痛を少な く容易に検査することができる。したがって，め まい.平衡障害の診断に VEMP を使用すること により，従来の検査では明らかにできなかった内 耳性㧍よび後迷路性障害の異常の診断, 患側の判 定, 障害部位の推定に役立つことが期待される。 文 献

1) Kiang NY, Christ AH, French MA, et al: Postauricular electric response to acoustic stimuli in humans. Quart Progr Rep Res Lab Electronics, M.I.T. 68: 218-225, 1963

2) Yoshie N, Okudaira T: Myogenic evoked potential responses to clicks in man. Acta Otolaryngol Suppl (Stockh) 252: 89-103, 1969

3) Bickford RG, Jacobson JL, Cody DTR: Nature of average evoked potentials to sound and other stimuli in man. NY Acad Sci 112: 204-218, 1964

4) Geisler CD, Frishkopf LS, Rosenblith WA: Extracranial responses to acoustic clicks in man. Science 128: 1210-1211, 1958

5 ) Townsend GL, Cody DTR: The averaged inion response evoked by acoustic stimulation: Its relation to the saccule. Ann Otol Rhinol Laryngol 80: 121-131, 1971

6) Cody DTR, Simonton KM, Hallberg OE: Automatic repetitive decompression of the saccule in endolymphatic hydrops (tack operation). Laryngoscope 77: 1480-1501, 1967

7 ) 吉江信夫 : 聴性誘発電位. 中西孝雄, 吉江信 夫編. 臨床誘発電位診断学. 49-134頁, 南山 堂, 東京, 1989

8) Colebatch JG, Halmagyi GM: Vestibular evoked potentials in human neck muscles before and after unilateral vestibular deafferentation. Neurology 42: 1635-1636, 1992

9 ) Colebatch JG, Halmagyi GM: Myogenic potentials generated by a click-evoked ves- tibulocollic reflex. J Neurol Neurosurg Psychiatry 57: 190-197, 1994

10) Halmagyi GM, Colebatch JG, Curthoys IS: New tests of vestibular function. Baillieres Clin Neurol 3: 485-500, 1994

11) Lim CL, Clouston P, Sheean G, et al: The influence of voluntary EMG activity and click intensity on the vestibular click evoked myogenic potential. Muscle Nerve 18: 12101213, 1995

12) Robertson DD, Ireland DJ: Vestibular evoked myogenic potentials. J Otolaryngol 24: 3-7, 1995

13) Lazzaro VD, Auartarone A, Higuchi $K$, et al: Short-latency trigemino-cervical reflexes in man. Exp Brain Res 102: 474-482, 1995

14) Ferber-Viart C, Duclaux R, Colleaux B, et al: Myogenic vestibular-evoked potentials in normal subjects: A comparison between responses obtained from sternomastoid and trapeqius muscles. Acta Otolaryngol (Stockh) 117: 472-481, 1997

15) De Waele C, Tran Ba Huy P, Freyss G, et al: Saccular dysfunction in Meniere's disease. Am J Otol 20: 223-232, 1999

16）將積日出夫, 長崎正男, 安村佐都紀, 他：音 刺激による胸鎖乳突筋誘発筋電図の検討.

Equilibrium Res 55: 538-544, 1996

17）將積日出夫, 長崎正男, 安村佐都紀, 他：音 刺激によるヒト前庭性誘発筋原性反応一温度 眼振反応之の解離例に関する検討一. Equilibrium Res 56: 354-359, 1997

18) Halmagyi GM, Colebatch JG: Vestibular evoked myogenic potentials in the sternomastoid muscle are not of lateral canal origin. Acta Otolaryngol Suppl (Stockh) 520: $1-3,1995$

19）將積日出夫, 渡辺行雄, 竹森節子, 他: 強大 音によるヒト前庭性頸部誘発笳原性反応一前 庭神経切断術，迷路破壊術症例での検討一。 Equilibrium Res 57: 157, 1998

20）將積日出夫, 竹森節子, 小林健二, 他: Vestibular evoked myogenic potentials の臨床 的意義. Equilibrium Res 58: 457, 1999 
21) Murofushi T, Halmagyi GM, Yavor RA, et al: Absent vestibular evoked myogenic potentials in vestibular neurolabyrinthitis: $A$ indication of inferior vestibular nerve involvement? Arch Otolaryngol Head Neck Surg 122: 845-848, 1996

22) Murofushi T, Matsuzaki M, Mizuno M: Vestibular evoked myogenic potentials in patients with acoustic neuromas. Arch Otolaryngol Head Neck Surg 124: 509-512, 1998

23) Tullio P: Sulla funzione delle varie parti del labirinto acustico. Arch Ital Otol Rinol Laringol 35: 230-267, 1924

24) Erlich MA, Lawson W: The incidence and significance of the Tullio phenomenon in man. Otolaryngol Head Neck Surg 88: 630635,1980

25) Pillsbury III HC, Postma DS: The Tullio phenomenon, fistula test, and Hennebert's sign: Clinical significance. Otolaryngol Clin North Am 16: 205-207, 1983

26) Fox EJ, Balkany TJ, Arenberg IK: The Tullio phenomenon and perilymph fistula. Otolaryngol Head Neck Surg 98: 88-89, 1988

27) Colebatch JG, Rothwell JC, Branstein A, et al: Click-evoked vestibular activation in the Tullio phenomenon. J Neurol Neurosurg Psychiatry 57: 1538-1540, 1994

28）浅井正嗣, 渡辺行雄, 大橋直樹, 他 : Equi Test ${ }^{\circledR}$ system による感覚, 運動機能の総合 的分析の診断的意義. 耳鼻臨床 補 36: 38-44, 1989

29）藤田尚男, 藤田恒夫 : 標準組織学 各論. 医 学書院, 東京, 1977

30) Cazals Y, Aran JM, Erre JP, et al: Acoustic responses after totoal destruction of the cochlear receptor: Brainstem and auditory cortex. Science 210: 83-86, 1980
31) Didier A, Cazals Y: Acoustic responses recorded from the saccular bundle on the eight nerve of the guinea pig. Hear Res 37 : 123-128, 1989

32) Cazals Y, Erre JP, Autouddrsu C: Eighth nerve auditory evoked responses recorded at the base of the vestibular nucleus in the guinea pig. Hear Res 31: 93-98, 1987

33) Murofushi T, Curthoys IS, Topple AN, et al: Responses of guinea pig primary vestibular neurons to clicks. Exp Brain Res 103: 174178,1995

34) Murofushi T, Curthoys IS: Physiology and anatomical study of click-sensitive primary vestibular afferents in the guinea pig. Acta Otolaryngol (Stockh) 117: 66-72, 1997

35) McCue MP, Guinan Jr J: Acoustically responsive fibers in the vestibular nerve of the cat. J Neurosci 14: 6058-6070, 1994

36) Young ED, Fernandez C, Goldberg JM: Responses of squirrel monkey vestibular neurons to audio-frequency sound and head vibration. Acta Otolaryngol (Stockh) 84: 352 $-360,1977$

37) Wilson VJ, MelVill Jones G: Mammmalian vestibular physiology. Plenum Press, New York, 1979

38) Kushiro K, Zakir M, Sato H, et al: Saccular and utricular inputs to sterno-cleidomastoid motoneurons of decerebrate cats. Exp Brain Res 126: 410-416, 1999

39) Colebatch JG, Rothwell JC: Vestibularevoked EMG responses in human neck muscles. J Physiol (Lond) 473: 18, 1993

$$
\left(\begin{array}{l}
\text { 原稿到着 : 平成11年11月 } 9 \text { 日 } \\
\text { 別刷請求先 : 將積日出夫 } \\
\text { 个930-0194 富山市杉谷 } 2630 \\
\text { 富山医科薬科大学耳鼻咽喉科学教室 }
\end{array}\right)
$$

